\title{
Anti Corruption Attitude Of Students As A Corruption Measure Of Criminal Measures
}

\author{
Yusrianto Kadir \\ Faculty of Law, Universitas Gorontalo \\ email: yusrikadir@gmail.com
}

\begin{abstract}
This study aims to explain the development of character in changing the legal behavior of students and integrative model of character building in the prevention of corruption. The theoretical approach is directed to two main approaches namely the integration of anticorruption values and the formation of environments that are not permissive to corruption. The method used through the positivist legal approach and sourced from primary, secondary, and tertiary legal materials. The result of the discussion shows character education should involve not only the aspects of good knowledge (moral knowing), but also feel good or loving good (moral feeling), and good behavior (moral action). The main components forming behavioral intentions are Attitude toward behavior, Subjective norms, Control belief. The expected conclusion of student anti-corruption behavior targeted is the consistency of anti-corruption amid the reality of the external environment. Consistency is expected to further increase into the courage of students to be the vanguard in inviting people to do zero-tolerance against acts of corruption.
\end{abstract}

Keywords: character building; anti corruption; prevention of corruption;

\section{INTRODUCTION}

Character is the nature that is brought by each individual, which each person has their own character. Understanding more characters lead to the moral and personality of a person, of course, which is positive. The character of an individual is formed since he was small due to genetic and environmental influences. The process of character formation, whether consciously or unconsciously, will affect the way the individual views himself and his environment and will be reflected in his or her daily behavior. Universities as institutions of higher education are one of the most important resources. ${ }^{1}$

The character is the values of human behavior related to God Almighty, self, fellow human, environment, and nationality embodied in thoughts, attitudes, feelings, words, and deeds based on religious norms, law, etiquette, culture, and customs. So for students, it is very important to get character education, it aims to strengthen morals and praiseworthy nature for learners (in this case students). Because intelligence in the field of education alone is not enough without the provision of moral and strong character. So

\footnotetext{
${ }^{1}$ Fidyani Fitri, https://fidyanifitri.wordpress.com/2012/07/02/pentingnya-pendidikan-karakter-dikalangan-
} mahasiswa/ (diakses tanggal 7 Juli 2017). 
that when the student plunge in the community there will be no misuse of knowledge learned during school.

As we see today, where smart people abuse their cleverness to commit criminal acts such as corruption or terrorism. The cleverness in question is a planned undertaking undertaken by an educated actor because of his expertise, his professionalism in a particular field, or because of his authority and position. For example, corruption, because the limits of the perpetrators who can be charged with Corruption Act is limited to the State Civil Apparatus, state organizers, or any party that utilizes state finances. Potential perpetrators referred only to those who have certain educational qualifications, in other words, the perpetrators of corruption are people who are educated in the sense narrow. ${ }^{2}$ If only they had a strong character and manners, surely it would not have happened. So for reasons of kindness, it is necessary to emphasize the importance of character education for students. Therefore we must transform our character into a successful character. The character of success is to work hard to achieve something we want, never complain about any risks we face. Because for the next few years is needed are people who have good character.

Academically, character education is interpreted as value education, character education, moral education, character education, or moral education whose purpose is to develop the ability of learners to give good decisions, to maintain goodness, and to realize the good in everyday life with all the heart. Character education as an educational concept that inculcates manners that involves aspects of knowledge (cognitive), feeling (feeling), and action (action) is a solution to improve the character and morals of the nation. Practically, character education is a system of planting good values to the citizens of the school or campus which includes the components of knowledge, awareness or willingness, and actions to implement those values, whether in dealing with God Almighty, fellow human beings, the environment, as well as the nation and nation to become a whole human being. ${ }^{3}$

The desire to be a democratic nation, free from corruption, collusion and nepotism (KKN), respect and obey the law are some of the nation's desired character in the life of society, nation and state. However, the fact that there is exactly the opposite phenomenon. Horizontal and vertical conflicts characterized by violence and unrest are ubiquitous, accompanied by a spiral of regionalism and primordialism that can threaten the institution of the nation; the practice of corruption, collusion and nepotism has not

\footnotetext{
${ }^{2}$ Yusrianto Kadir (Disertasi), 2016. Hakekat Penerapan Pendidikan Anti Korupsi di Perguruan Tinggi Sebagai Upaya Pencegahan Tindak Pidana Korupsi. Program Doktor IImu Hukum, Universitas Muslim Indonesia Makassar.

${ }^{3}$ Yusfita Kumala Dewi, Math Didactic: Jurnal Pendidikan Matematika Vol. 1, No. 2, Mei - Agustus 2015 @ STKIP PGRI Banjarmasin, lihat juga Aswari, A., \& Perdana, A. H. (2018, June 5). SANKSI PELAJAR RAMAH LINGKUNGAN. https://doi.org/10.31227/osf.io/5zxb8.
} 
subsided even further; the demanding democratic democracy turns into a democracy that goes too far and leads to anarchism; social and political politeness fades on the various levels of life of society, nation, and state; the intelligence of the nation's life mandated by the founders of the state increasingly invisible, all of which show the unturned noble values of the nation. ${ }^{4}$

Among the students and students of moral decadence is no less apprehensive. The behavior of ethical, moral and legal bumping from mild to severe still often shown by students and students. The habit of cheating when the test or test is still done. The desire to pass easily and effortlessly during a national exam causes them to seek answers in an unethical way. They are looking for leaked answers from various sources that are not clear. Especially if the desire to pass easily is institutional because it is engineered or conditioned by the leadership of educational institutions systemically. In those who do not pass, there are those who take acts of recklessness with self-harm or even suicide. Unethical behavior is also shown by students. Plagiarism or plagiarism of scientific work among students is also still massive. There is even done by doctoral program students. All this shows the fragility of characters among students and students. ${ }^{5}$

Another thing that is symptomatic among students and students in the form of delinquency. Some of them are a brawl between students and students. In some big cities, student brawls become a tradition and form a fixed pattern, so that among them form a mortal enemy. Tawuran also often done by the students as done by a group of students at certain universities in Makassar. Another form of delinquency by students and students is to drink alcohol, promiscuity, and drug abuse that can lead to depression and even HIV / AIDS. Another phenomenon that tarnished the image of students is and educational institutions are rampant gang learners and motor aisles Their behavior often leads to even bullying that disturbs society and even criminal acts such as logging, torture, even murder. All the negative behaviors among students and students mentioned above, clearly indicate the fragility of the character is quite severe one of which is caused by the not optimal character development in educational institutions in addition to environmental conditions that do not support. ${ }^{6}$

Strengthening the character became one of the priority programs of President Joko Widodo (Jokowi) and Vice President Jusuf Kalla. In Nawa, ideals mentioned that the government will do the character revolution of the nation. The Ministry of Education and Culture implements the strengthening of the nation's successor character through the movement of Strengthening Character Education (PPK) which was launched in 2016. In accordance with President Joko Widodo's direction, character education at elementary

\footnotetext{
${ }^{4}$ ibid

${ }^{5}$ https://aridianadityo.wordpress.com/2012/12/15/pentingnya-pendidikan-berkarakter-bagi-mahasiswa/

${ }^{6} \mathrm{http} / / /$ www.tubanjogja.org/2014/12/15/pentingnya-pendidikan-berkarakter/
} 
education level gets a bigger portion than education which teaches knowledge. For elementary school by 70 percent, while for junior high school by 60 percent. $^{7}$

The Ministry of Education and Culture (Kemendikbud) continually strives to mourn the jaws through government priority programs in education and culture. During the two years of the Working Cabinet, Kemendikbud increased the Human Development Index (HDI) by 0.75 points from 68.8 in 2014 to 69.55 in 2015, with the education index rising by 0.82 points from 60.18 to 61.00 in 2015. The increase in HDI is due to an increase in the average length of schooling population aged 25+ from 7.73 years to 7.83 years in 2015 and an increase in average school life expectancy increased from 12.39 years to 12.55 years in $2015 .^{8}$

Human Development Index above unfortunately only describes the output that does not lead to the development of the nation's character as a whole. Targets in the first and higher levels of higher education do not reflect continuity efforts in higher education, so the HDI target of secondary education does not guarantee HDI at higher education levels. So the role of college is only more directed to the development of knowledge competence (cognitive) only. Though college graduates are expected to immediately adjust to the work environment, which of course not only rely on knowledge competence only but more includes other supporting competencies.

Although education is only one of the variables that influence the formation of anti-corruption character, so it is expected to prevent the corrupt behavior, but education is a long-term investment in the whole human development index. University graduates who at least fill positions/jobs as Members of DPR and DPRD, Heads of Institutions / Ministries, Ambassadors, Commissioners, Governors, Mayors / Regents and Deputies, Echelon I / II / III, Judges, Prosecutors, Police, Lawyers, Private, Corporations, did not escape corrupt behavior, as the data below:

${ }^{7}$ https://www.kemdikbud.go.id/main/blog/2017/07/penguatan-pendidikan-karakter-jadi-pintu-masukpembenahan-pendidikan-nasional

${ }^{8} \mathrm{https}: / /$ www.kemdikbud.go.id/main/blog/2016/12/membangun-manusia-indonesia-unggul-berdaya-saing-danberkarakter 


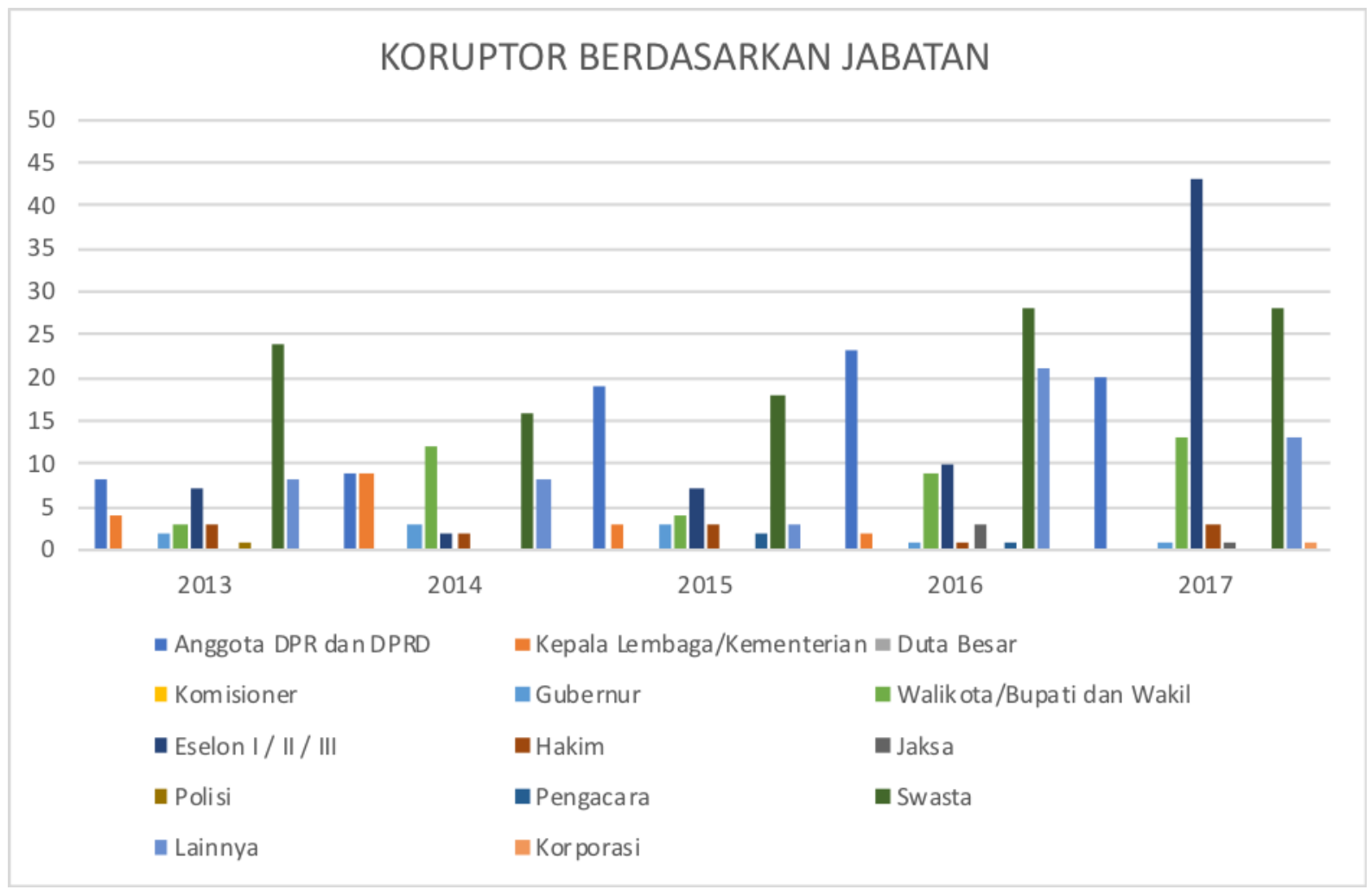

Source: acch.kpk.go.id

The above chart shows that from the last 5 years the biggest corruption actors are from echelon I / II / III in government institutions. Even if the corruptive behavior has many variables that effect, but the provision of cognitive, affective, and psychomotor competence is established through education that is quite influential in the prevention of corruption behavior. ${ }^{9}$

Various efforts have been made to improve access and quality of education services including strengthening the role of vocational education as a strategic step of increasing the productivity and competitiveness of the nation and strengthening the role of culture in national education as an effort to revolutionize the nation's character. ${ }^{10}$ Implementation of Strengthening Character Education (KDP) will become the main motor of government policy in education and culture.

We want to build Indonesian people who have character, virtuous, and noble. Our nation also wants to have a superior and noble civilization. Such a civilization can be achieved if our society is also a good society. And an ideal society like this we can realize

\footnotetext{
${ }^{9}$ Yusrianto Kadir, 2016, Disertasi: Hakekat Penerapan Pendidikan Anti Korupsi di Perguruan Tinggi Sebagai Upaya Pencegahan Tindak Pidana Korupsi. Program Doktor IImu Hukum. UMI Makassar.

${ }^{10}$ Buana, A. P., Aswari, A., Said, M. F., \& Arifin, M. Y. R. (2018). Responsibility Parking Service Business to The Protection Of Consumer Of The Parking Services in Makassar. Substantive Justice International Journal of Law, 1(1), 23-32.
} 
when the human beings of Indonesia is a morally good human, moral human, and ethical good, and humans who speak and behave well as well.

There are five main character values sourced from Pancasila which is actually also the role of universities in developing anti-corruption attitudes in the student environment, which became the priority of developing the KDP movement; namely religious, nationalism, integrity, independence, and mutual cooperation. Each value does not stand and develop independently but interacts with each other, develops dynamically, and forms a personal whole. ${ }^{11}$

For that, we need to find the best way to build and develop human character and nation of Indonesia in order to have good character, superior and noble. The right endeavor for that is through education because education has an important and central role in the development of human potential, including mental potential. Through education is expected to happen a transformation that can build positive character, and change the character of the bad to be good. Ki Hajar Dewantara explicitly states that education is an effort to promote the growth of character (inner strength, character), mind (intellect), and the body of children. ${ }^{12}$ So clearly, education is the main vehicle for cultivating good character. The problems identified in this paper are, first; how should the formation of characters that support the application of anti-corruption attitudes, and secondly; how the internalization process of the application of anti-corruption attitudes among students.

Efforts to prevent the culture of corruption in the community first can be done by preventing the development of mental corruption in Indonesian children through education. The spirit of anti-corruption that should be a study is the planting of thought patterns, attitudes, and anti-corruption behavior through schools because school is a process of culture. The formal education sector in Indonesia can play a role in meeting corruption prevention. Preventive measures (prevention) can indirectly through two approaches (approach), first: make learners become targets, and second: use the empowerment of learners to suppress the environment in order not Permissive to corruption.

To participate in the anti-corruption and eradication movement, there are two models that educational institutions can undertake in developing an integrative-inclusive anti-corruption education curriculum for education. First, the educational process must foster social-normative concerns, build objective reasoning, and develop a universal perspective on the individual. Second, education should lead to strategic seeding, the individual's consistent and robust personal qualities in social engagement. The

\footnotetext{
${ }^{11} \mathrm{https}$ ://ristekdikti.go.id/siaran-pers-kemendikbud-penguatan-pendidikan-karakter-pintu-masuk-pembenahanpendidikan-nasional/

${ }^{12} \mathrm{Ki}$ Hajar Dewantara dengan tegas menyatakan bahwa pendidikan merupakan daya upaya untuk memajukan bertumbuhnya budi pekerti (kekuatan batin, karakter), pikiran (intellect), dan tubuh anak.
} 
integrative-inclusive model of anti-corruption education in applicative education is more domiciled as an approach to contextual-based learning.

Character education is based on six ethical values, that everyone can agree on values that do not contain political, religious or cultural biases. Some of these things can be explained and to be easily understood about the six pillars of character education ${ }^{13}$, as follows:

1. Trustworthiness Honest, do not cheat, plagiarize or steal, be reliable, do what you say you will do, have the courage to do the right thing and build a good reputation, obedient.

2. Respect Be tolerant of difference, use courtesy, not a bad language, consider other people's feelings, do not threaten, beat or hurt others, reconcile with anger, humiliation, and disagreement.

3. Responsibility (Responsibility) Always do your best, use self-control, discipline, think before acting, consider the consequences, be responsible for the choices already taken.

4. Fairness (Justice) Play by the rules, take as necessary and share, openminded, listening to others, do not take profit from others, carelessly.

5. Caring (Caring) Be loving and show you care, gratitude, forgive others, helping people in need.

6. Citizenship Make schools and communities better, work together, involve themselves in community affairs, be good neighbors, obey laws and rules, respect authority, protect the environment.

\section{METHOD}

The domain of this article is in the realm of legal science on the nonpenal side or prevention with the type of approach used is the normative approach. This approach examines the matters using the positivist concept of legislation by integrating the concept of prevention of corruption with the integration of character education in Education which states that the law is identical with written norms, but further to measure the workings of the law should be supported by a non-legal approach, which in this case is the internalization of moral values and propriety in the educational environment. Data were obtained through primary legal materials, secondary legal materials, and tertiary legal materials.

\footnotetext{
${ }^{13}$ Nanda Ayu Setiawati, Pendidikan Karakter Sebagai Pilar Pembentukan Karakter Bangsa, Prosiding Seminar Nasional Tahunan Fakultas IImu Sosial Universitas Negeri Medan Tahun 2017 Vol. 1 No. 1 2017, Hal. 348-352
} 


\section{ANALYSIS AND DISCUSSION}

\section{Character Formation as a Form of Anti Corruption Attitude}

According to the Ministry of National Education, the character is the character, character, morality, or personality formed from the internalization of virtues that are believed and used as the basis for the worldview, thinking, attitude and action. Character terminology contains at least two things: values (values) and personality. As a reflection of the whole personality, the character bases itself on the values of society. The underlying values of individual thought and behavior are embedded in a process of internalizing values that are in accordance with the culture adopted by society. This internalization process then forms the character of an individual. ${ }^{14}$

Mounier proposes two ways of interpretation by looking at characters as two things, first, as a set of conditions that are given away or simply exist, which are more or less forced within us. Such a character is regarded as something that has existed from the past (given). Second, the character is understood as the level of power through which an individual is able to master the condition. Such a character is referred to as the desired process (willed) ${ }^{15}$. Thus, it can be concluded that the character is a dynamic condition of the anthropological structure of a distinct and distinct human being as a result of the integration of heart, mind, body, taste, and intention as a congenital condition accompanied by an attempt to self-perfection.

Character education can be interpreted as a valuable education, moral education, moral education, character education, which aims to develop the ability of learners to give good decisions bad, maintain what is good, and realize the goodness in daily life with a vengeance. The formation and development of character as an educational endeavor is expected to have a positive impact both for individuals as well as for their environment. Character education is an attempt to educate children to make wise decisions and practice them in everyday life, ${ }^{16}$ so they can make a positive contribution to their environment. ${ }^{17}$

Character education should involve not just aspects of good knowledge (moral knowing), but also feel good or loving good (moral feeling), and good behavior (moral action). Character education emphasizes the habit or habit that is constantly practiced and practiced. Thus, it can be concluded that character education is an effort to form and

\footnotetext{
14 Diptasari Wibawanti, Persepsi dan Perilaku Mahasiswa dalam Pendidikan Karakter (Studi Kasus Di Jurusan Pendidikan IImu Pengetahuan Sosial Fakultas Keguruan dan IImu Pendidikan Universitas Sebelas Maret)

${ }^{15}$ A, Doni Koesoema. 2007. Pendidikan Karakter: Mendidik Anak di Zaman Global. Jakarta: Grasindo.

16 ibid

${ }^{17}$ Kesuma, D., Triatna, C., \& dan Permana, J. (2011). Pendidikan Karakter: Kajian Teori dan Praktik di Sekolah. Bandung: PT Remaja Rosdakarya. Creative Education, Vol.7 No.2, February 24, 2016
} 
develop character that involves all aspects of human dimensions both cognitive, affective (emotional), and psychomotor (physical) by knowing, feeling and executing good behavior (knowing the good, loving the good, An acting the good) to become a habit or habit that is continuously practiced that is personal and social as a joint responsibility of government, society, schools, and parents.

Character education is expected to result in more positive behavioral changes. Behavior has a subjective meaning for every culprit, and Weber states that an action is a human behavior that has a subjective meaning to the perpetrators. Understanding the subjective meaning of an action means empathy, that is, how to place oneself in the frame of thinking of others acting, and situations and objectives seen according to the perspective. Character education is a conscious effort that considers goals and ways to achieve them. By Weber, this is referred to as an instrumental rational action, which includes consideration and conscious choice relating to the purpose and the tools used to achieve it.

The image of a work culture based on strong character (including trustworthiness and exemplary) and intelligent, is stated as follows: ${ }^{18}$

\begin{tabular}{|c|c|c|c|}
\hline No. & Characteristics & Defenitions & Indicator \\
\hline 1. & Commitment & $\begin{array}{l}\text { Determination that binds and } \\
\text { adheres to an educator to } \\
\text { perform his duties and } \\
\text { responsibilities as an educator }\end{array}$ & $\begin{array}{l}\text { Having vision sharpness } \\
\text { Sense of having (sense of } \\
\text { belonging) } \\
\text { To be responsible } \\
\text { (sense of responsibility) }\end{array}$ \\
\hline 2. & Component & $\begin{array}{l}\text { The ability of an educator in } \\
\text { organizing learning (teaching and } \\
\text { educating) and ability to solve } \\
\text { various problems in order to } \\
\text { achieve educational goals }\end{array}$ & $\begin{array}{l}\text { Always } \\
\text { self development } \\
\text { Experts in their field } \\
\text { - Inspire his profession } \\
\text { Has competence } \\
\text { pedagogy, personality, } \\
\text { social, and professional }\end{array}$ \\
\hline 3. & Hard Work & $\begin{array}{l}\text { Ability to direct or exert all effort } \\
\text { and sincerity, potential owned } \\
\text { until the end of a business until } \\
\text { the goal is achieved }\end{array}$ & $\begin{array}{l}\text { Working sincerely and } \\
\text { truly } \\
\text { - Working beyond the target } \\
\text { (extra ordinary process) } \\
\text { - Productive (out-standing } \\
\text { result) }\end{array}$ \\
\hline 5. & Simplicity & $\begin{array}{l}\text { Ability to actualize something } \\
\text { effectively and efficiently }\end{array}$ & $\begin{array}{l}\text { - Understandably } \\
\cdot \text { Not fancy } \\
\cdot \text { Not excessive } \\
\cdot \text { Appropriate }\end{array}$ \\
\hline 6. & Closeness & $\begin{array}{l}\text { The ability to interact dynamically } \\
\text { in the emotional fabric between } \\
\text { lecturers and learners in order to } \\
\text { achieve the goals of learning / } \\
\text { education }\end{array}$ & $\begin{array}{l}\text { - Attention on } \\
\text { student (student } \\
\text { centered) } \\
\text { - Learning centered } \\
\text { - Relationships } \\
\text { emotional ones } \\
\text { harmonious }\end{array}$ \\
\hline
\end{tabular}

${ }^{18}$ opcit 


\begin{tabular}{|c|c|c|c|}
\hline 7. & Maximum Service & $\begin{array}{l}\text { Ability to help or serve or meet } \\
\text { the needs of learners optimally }\end{array}$ & $\begin{array}{l}\text { - Fulfillment of Standards } \\
\text { Minimal Service } \\
\text { (SPM) } \\
\text { - Satisfaction } \\
\text {. Fast and responsive } \\
\text { - Fast service } \\
\text {. Proactive }\end{array}$ \\
\hline 8. & Smart & $\begin{array}{l}\text { Ability to quickly understand } \\
\text { and understand, responsive, } \\
\text { sharp in analyzing and able to } \\
\text { find solutions alternative, and } \\
\text { able to solve the problem } \\
\text { (intelligent intellectual) } \\
\text { - Ability to deliver } \\
\text { meaning/value to the various } \\
\text { activities undertaken so that the } \\
\text { result is optimal (intelligent } \\
\text { emotionally and spiritually) }\end{array}$ & $\begin{array}{l}\text { - Responsive, analytical, } \\
\text { innovative, and solutive }\end{array}$ \\
\hline
\end{tabular}

There are several things to consider in building the ideology of anti-corruption education. ${ }^{19}$

First, place education as a means of character building. German Pedagogue FW Foerster $^{20}$ say that the main essence of education is character formation. In Foerster's view, there are four basic characteristics in character education, namely the order of the interior in which every action is measured by the hierarchy of values, the coherence that gives courage, is steadfast in principle, not easily vacillated in new situations or fear of risk, giving autonomy in internalizing rules outside becomes personal value, and builds firmness and loyalty in the fight for truth and justice. The maturity of the four basic values of the Foerster will build the form of a person in all his actions. With the four basic values that will be born a strong person and ready to hit the inequality that hit the community, especially corruption.

Second, create a curriculum that always condemns corruption as a social crime. In every subject matter, an educator should not only explain the textual meaning of scientific theory but also be able to contextualize the phenomenon of social inequality that occurs in society. With the integration of theory and reality, the educational curriculum, in addition to not dull students, is also able to lead them to a vast and powerful knowledge hollow. They are not only rich with knowledge, but also life experiences of stock in the future.

Third, no real action in eradicating corruption. This concrete action can be in the form of cooperation with the judiciary that drags the corruptors or non-governmental organizations concerned with corruption eradication policies. With this concrete action, students or students will see the real price of corruption in Indonesia and explain to them

19 http://id.beritasatu.com/home/korupsi-dan-pendidikan-karakter/26509 diakses tanggal 10 juli 2017, pukul 12:40 wita.

${ }^{20} \mathrm{https}$ ://indrajuliano.wordpress.com/2011/06/23/pendidikan-karakter/ 
that the corruptors are the tie people who have completed their education to the highest level. That way, the students will be "stranded" to rise up to restore the morality of education and will eventually be dedicated positively to the nation's survival.

Fourth, build a new flow cross-sectoral education. Here we need to establish massive movements in various central and local educational institutions in opposing the actions of the corrupt. The new wave will always be covered by the media and will gradually become the mainstream of future humanitarian thinking. By becoming a new mainstream then anticorruption education is not just a discourse, but a movement that is very important for the sake of the future of the nation. ${ }^{21}$

Anti-corruption education in the form of special courses seems to make corruption as knowledge, or at least the study materials of lecturers and students. The difference is, the expectation is that knowledge is not to be applied, but avoided. Who knows the realization of a collective determination to not go along with corruption when graduating later, including the corruption that actually happens in college itself. Cleaning up the house and self is much more important than examining the taxonomy of corruption in college..$^{22}$

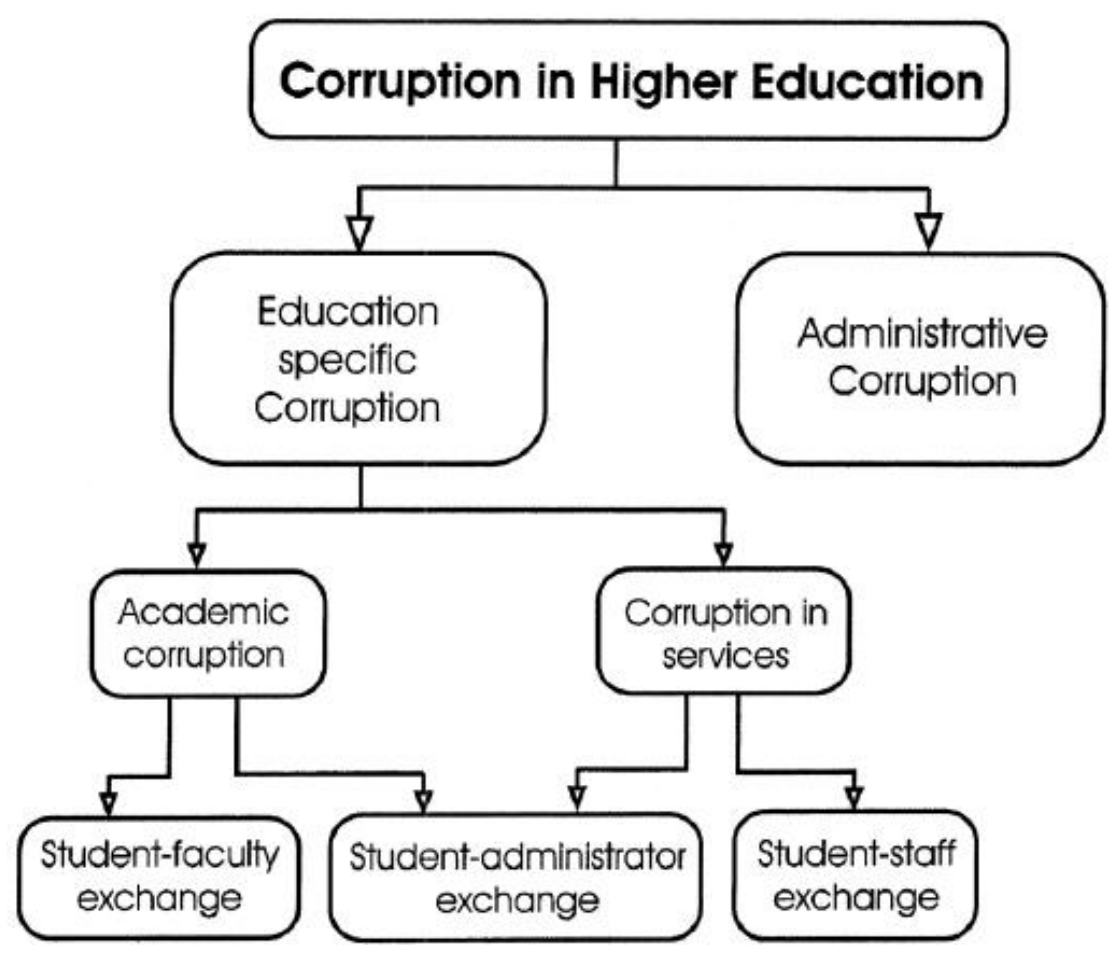

${ }^{21}$ Thalib, H., Ramadhan, A., \& Djanggih, H. (2017). The Corruption Investigation In The Regional Police of Riau Islands, Indonesia. Rechtsidee, 4(1), 71-86.

${ }^{22}$ Yusrianto Kadir, 2018. Kebijakan Pendidikan Anti Korupsi di Perguruan Tinggi. Jurnal Gorontalo Law Review. ISSN 2416-5030 
Some ideological steps mentioned above are expected to be the most effective dispels against social diseases that have ruined the life of this nation. Corruption and its twin brothers, collusion, and nepotism have been a "trilogy" of disease that is gnawing at this nation. Do not let this nation's "trilogy" disease continue to live and undermine our common life. Therefore, anticorruption education should be the god of salvation, a blueprint that can bring progress to the nation in the future.

\section{Internalizing the Intention of Student Anti Corruption Behavior}

The essence of corruption is the behavior that conscious and deliberate individuals emerge. Psychologically there are several components that cause the behavior to appear. Any behavior that is made consciously derives from the potential behavior (behavior that has not manifested itself), which is termed by intention. Potential behavior intentions are attitudes, which consists of three factors: cognition, affection and psychomotor, in which all three synergize to form a certain behavior. Thus, the corruption / anti-corruption behavior generated by individuals is based on the existence of corruption I anti-corruption behavior intent in which the synergy of three factors of cognition, affection and psychomotor occurs. Anti-corruption course methods should provide a balanced synergy between the three components so that it can really serve to strengthen the student's anti-corruption behavior potential. Basically, the anti-corruption potential is in each individual student, and it is the duty of the lecturer to strengthen it. ${ }^{23}$

Still related to the intentions of anti-corruption behavior, Fishbein, and Ajzen ${ }^{24}$ explained there are 3 (three) main components forming behavior intentions are:

a. Attitude toward behavior (ATB): influenced by behavioral belief, positive or negative evaluation of a particular behavior - reflected in words such as true-false, agree-disagreeable, good-bad, etc. Negative evaluation of corrupt behavior and a positive evaluation of anti-corruption will increase the intention (potential) to behave in an anti-corruption manner.

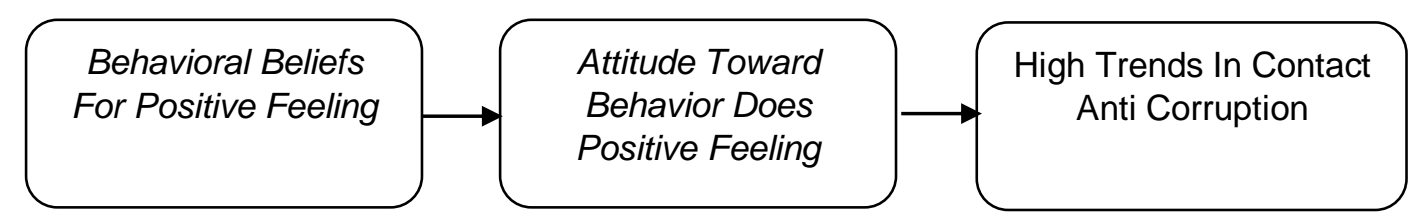

b. Subjective norms (SN): influenced by subjective norms around individuals who expect the individual to behave in a certain way or not. For example religious norms (religious individuals), social norms, family norms, or when people who are important to individuals or tend to be obeyed by individuals consider anti-

${ }^{23}$ Yusrianto Kadir (Disertasi), 2016, Hakekat Penerapan Pendidikan Anti Korupsi di Perguruan Tinggi Sebagai Upaya Pencegahan Tindak Pidana Korupsi, Program Doktor IImu Hukum, Universitas Muslim Indonesia

${ }^{24}$ Fishbein, M., \& Ajzen, I. (1975). Belief, Attitude, Intention, and Behavior: An Introduction to Theory and Research.Reading, MA: Addison-Wesley. 
corruption behaviors as positive, it will increase the intention of (potentially) anticorruption behavior.

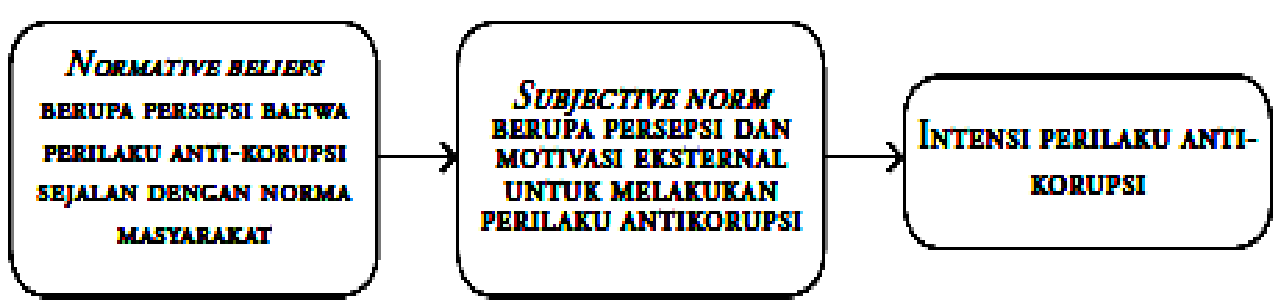

c. Control belief $(\mathrm{CB})$ : which is influenced by perceived behavior control, namely the reference difficulty and ease to elicit a behavior. It deals with the source an opportunity to realize that behavior. For example, the environment around a corrupt individual or a large/easy corruption opportunity will increase the intention of the individual to engage in the corrupt behavior, and vice versa.

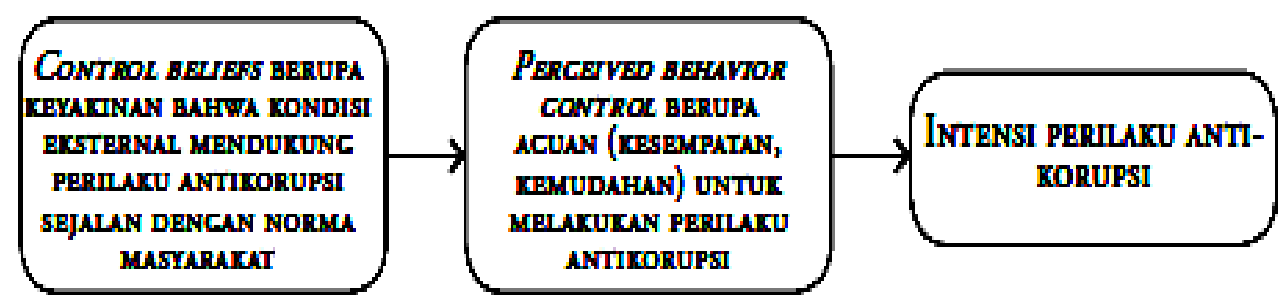

Ideally, the student's anti-corruption behavior targeted is the consistency of anticorruption amidst the reality of the still very corrupt external environment. Consistency is expected to further increase into the courage of students to be the vanguard in inviting people to do zero-tolerance against acts of corruption. Planned Behavior theory is used as an analytical tool in measuring the effectiveness of Anti-Corruption course in students. The University of Paramadina conducted this study on the students of Anti-Corruption subjects one and a half years later. The suggested findings are of concern to every university that designs Anti-Corruption Education ${ }^{25}$ :

1. Concepts and discourses on corruption and anti-corruption are indispensable and proven capable of providing sufficient cognitive effects for students' frame of mind.

2. Emphasis on the existence of legal norms and anti-corruptive social norms proved able to give students a strong sense of community support.

3. But the commitment of students to consistently behave and act anti-corruptively in off-campus life is still often tangent to the reality of corruption practices (petty corruption) encountered in almost all lines. The imbalance between educational

\footnotetext{
${ }^{25}$ Herdiansyah, Haris. 2010. Metode Penelitian Kualitatif untuk IImu-ilmu Sosial. Jakarta: Salemba Humanika.
} 
efforts and bureaucratic system reform is feared will potentially erode the anticorruption personality that has been fostered inside the campus.

It can be concluded that in prevention through education it must be supported in parallel with the improvement and improvement of integrity by the government and society. While in education itself, finally the teacher must play the role as a motivator for the students.

\section{CONCLUSION}

Character education can be interpreted as a valuable education, moral education, moral education, character education, which aims to develop the ability of learners to give good decisions bad, maintain what is good, and realize the goodness in daily life with a vengeance. The formation and development of character as an educational endeavor is expected to have a positive impact both for individuals as well as for their environment. This is in Megawangi's opinion that character education is an attempt to educate children to make wise decisions and practice them in everyday life so that they can contribute positively to their environment. Ideally, the student's anti-corruption behavior targeted is the consistency of anti-corruption amidst the reality of the still very corrupt external environment. Consistency is expected to further increase into the courage of students to be the vanguard in inviting people to do zero-tolerance against acts of corruption.

\section{REFERENCE}

A, Doni Koesoema. (2007). Pendidikan Karakter: Mendidik Anak di Zaman Global. Jakarta: Grasindo.

Aswari, A., \& Perdana, A. H. (2018). SANKSI PELAJAR RAMAH LINGKUNGAN. https://doi.org/10.31227/osf.io/5zxb8

Buana, A. P., Aswari, A., Said, M. F., \& Arifin, M. Y. R. (2018). Responsibility Parking Service Business to The Protection Of Consumer Of The Parking Services in Makassar. Substantive Justice International Journal of Law, 1(1), 23-32.

Diptasari Wibawanti, Persepsi dan Perilaku Mahasiswa dalam Pendidikan Karakter (Studi Kasus Di Jurusan Pendidikan IImu Pengetahuan Sosial Fakultas Keguruan dan IImu Pendidikan Universitas Sebelas Maret)

Fishbein, M., \& Ajzen, I. (1975). Belief, Attitude, Intention, and Behavior: An Introduction to Theory and Research.Reading, MA: Addison-Wesley.

Herdiansyah, Haris. (2010). Metode Penelitian Kualitatif untuk IImu-ilmu Sosial. Jakarta: Salemba Humanika. 
Hidayatullah, M.F. (2009). Guru Sejati: Membangun Insan Berkarakter Kuat dan Cerdas. Surakarta: Yuma Pustaka.

Kesuma, D., Triatna, C., \& dan Permana, J. (2016). Pendidikan Karakter: Kajian Teori dan Praktik di Sekolah. Bandung: PT Remaja Rosdakarya. Creative Education, Vol.7 No.2, February 24.

Kusuma, (2011). Pendidikan Krakter Strategi Mendidik Anak di Zaman Global Gramedia, Jakarta

Nanda Ayu Setiawati, (2017). Pendidikan Karakter Sebagai Pilar Pembentukan Karakter Bangsa, Prosiding Seminar Nasional Tahunan Fakultas IImu Sosial Universitas Negeri Medan Tahun 2017 Vol. 1 No. 1, p. 348-352.

Ratna Megawangi, (2004). Pendidikan Karakter; Solusi yang Tepat untuk Membangun Bangsa, Bogor: Indonesia Heritage Foundation.

Sunarto, Kamanto. (2004)Pengantar Sosiologi. Jakarta: Penerbit Fakultas Ekonomi, Universitas Indonesia.

Thalib, H., Ramadhan, A., \& Djanggih, H. (2017). The Corruption Investigation In The Regional Police of Riau Islands, Indonesia. Rechtsidee, 4(1), 71-86.

Wade, Carole, dan Carol Tavris. (2007). Psychology,9th edition, bahasa indonesia language edition. Jakarta : Penerbit Erlangga.

Winataputra. U.S. (2010). Implementasi Kebijakan Nasional Pembangunan Karakter Bangsa melalui Pendidikan Karakter.

Yusrianto Kadir (Disertasi), (2016). Hakekat Penerapan Pendidikan Anti Korupsi di Perguruan Tinggi Sebagai Upaya Pencegahan Tindak Pidana Korupsi. Program Doktor IImu Hukum, Universitas Muslim Indonesia Makassar.

Yusfita Kumala Dewi, Math Didactic: Jurnal Pendidikan Matematika Vol. 1, No. 2, Mei Agustus 2015 @ STKIP PGRI Banjarmasin.

Yusrianto Kadir, (2018). Kebijakan Pendidikan Anti Korupsi di Perguruan Tinggi. Jurnal Gorontalo Law Review. ISSN 2416-5030

https://www.kemdikbud.go.id/main/blog/2017/07/penguatan-pendidikan-karakter-jadipintu-masuk-pembenahan-pendidikan-nasional

https://fidyanifitri.wordpress.com/2012/07/02/pentingnya-pendidikan-karakter-dikalanganmahasiswa/ diakses tanggal 7 Juli 2017, pukul 10:24 